\title{
Use of alternative extender added of fructose aiming the cryopreservation of boar semen
}

\section{Utilização de diluente alternativo acrescido de frutose visando à criopreservação de sêmen suíno}

\author{
Ludymila Furtado CANTANHÊDE'; Eduardo Nunes de FREITAS ${ }^{1}$; Tatyane Bandeira BARROS ${ }^{1}$; \\ Daianny Barboza GUIMARÃES ${ }^{1}$; Aline Viana DIAS ${ }^{1}$; Ricardo TONIOLLI²
}

\footnotetext{
${ }^{1}$ Universidade Estadual do Ceará, Faculdade de Veterinária, Programa de Pós-Graduação em Ciências Veterinárias, Fortaleza - CE, Brazil ${ }^{2}$ Universidade Estadual do Ceará, Faculdade de Veterinária, Laboratório de Reprodução Suína e Tecnologia de Sêmen, Fortaleza - CE, Brazil
}

\begin{abstract}
This study aimed to analyse skimmed milk powder (SMP) and fructose in a new cooling curve to freeze boar semen. A total of 49 semen samples from seven boars were cryopreserved using the new curve with the addition of glucose and fructose to the refrigerating diluents Beltsville Thawing Solution (BTS + G; BTS + F) and skimmed milk powder (SMP $+\mathrm{G}$; SMP + F), totaling four experimental groups for analysis. At the end of the curve, aliquots of semen were packaged in $0.5 \mathrm{ml}$ straws and kept in liquid nitrogen. During the cooling curve, SMP mean spermatic vigor and motility were greater than the BTS $(\mathrm{p}<0.05)$ ones. After thawing, a decrease of spermatic force and motility in both extenders was observed, where the BTS presented spermatic vigor $(2.1 \pm 0.55)$ and motility $(38 \pm 21.8)$, presenting better results ( $\mathrm{p}$ $<0.05)$. There was no statistical difference between sugars added to the BTS and SMP in spermatic force and motility $(\mathrm{p}>0.05)$, although the use of fructose allowed an equalization of motility between the SMP and BTS ( $p>0.05)$. The functionality of membrane was better preserved with the addition of fructose, in both extenders. The rate of sperm viability was significantly higher in extender containing glucose and SMP (71.8 \pm 12.5$)$. The percentage of intact acrosome was higher on the treatment containing glucose, independent of the extender (BTS + G: 81.8 \pm 7.2, SMP + G: $81.4 \pm 14.2$ ). To conclude, the results suggest that the BTS is still the best option to cryopreserve and fructose could be used in boar semen cryopreservation in a new cooling curve.
\end{abstract}

Keywords: Cryopreservation. Cooling curve. Sperm. Alternative extender.

\section{Resumo}

Este trabalho analisou o emprego do leite em pó desnatado (LPD) e frutose em uma nova curva de resfriamento para de sêmen suíno. Um total de 49 amostras de sêmen de sete varrões foi criopreservado, utilizando a nova curva de resfriamento com glicose e frutose adicionadas aos diluentes Beltsville Thawing Solution (BTS + D; BTS + F) e leite em pó desnatado ( $\mathrm{LPD}+\mathrm{D}$; LPD $+\mathrm{F}$ ), totalizando quatro grupos experimentais para análises. Ao final da curva, as alíquotas de sêmen foram envasadas em palhetas de $0,5 \mathrm{~mL}$ e mantidas em nitrogênio líquido. Durante a curva de resfriamento, as médias de vigor e de motilidade espermática do LPD foram maiores do que as do BTS ( $\mathrm{p}<0.05$ ). Após descongelação, observou-se queda do vigor e motilidade em ambos diluentes, com o BTS apresentando melhores resultados de vigor $(2,1 \pm 0,55)$ e de motilidade $(38 \pm 21,8)(\mathrm{p}<0,05)$. Entretanto, o uso da frutose permitiu equiparação dos valores da motilidade entre LPD e BTS ( $p>0,05)$. A funcionalidade da membrana foi melhor preservada com adição da frutose, em ambos os diluentes. Os dados de vitalidade espermática foram significativamente maiores no diluente contendo glicose e LPD $(71,8 \pm 12,5)$. A porcentagem de acrossomas intactos foi maior no tratamento que continha glicose, independentemente do diluente utilizado (BTS + G: $81,8 \pm 7,2$, SMP + G: 81,4 $\pm 14,2$ ). Os resultados obtidos indicaram que o BTS ainda é a melhor opção de criopreservação e que a frutose pode ser utilizada para criopreservação de sêmen de varrão na nova curva de resfriamento.

Palavras-chave: Criopreservação. Curva de resfriamento. Espermatozoide. Diluente alternativo. 
Correspondence to:

Ricardo Toniolli

Universidade Estadual do Ceará, Faculdade de Veterinária

Av. Paranjana, 1700 - Campus Itaperi

CEP 60740-000, Fortaleza, CE, Brazil

e-mail: ricardo.toniolli@uece.br

Received: 27/05/2016

Approved: 28/11/2017

\section{Introduction}

The use of frozen semen is still limited in boars. Currently, sperm cryopreservation represents an important biotechnological tool to preserve the genetic potential of breeding, allowing its use for long periods (BORTOLOZZO et al., 2005).

The success of semen cryopreservation depends on the maintenance of sperm integrity and functionality, which is linked to cellular metabolism decreasing and the use of solvents that can promote good in vitro cell survival. The extenders are important, because they provide a favorable environment for sperm, and its composition is one of the factors that affect the quality of these cells after thawing (DERIVAUX, 1982). The sugars and lipoproteins from milk and egg yolk are essential for semen preservation because they act as external cryoprotectants against the formation of ice crystals inside the cells (AMANN; PICKETT, 1987) by progressively increasing the concentration of solutes in the extracellular environment. Various techniques have been tested with different types and concentrations of cryoprotectants and extenders, exposure temperature thereof, cooling curves, stabilizing the cytoskeleton, thawing protocols and removal of cryoprotectants (BORTOLOZZO et al., 2005).

Several factors may affect sperm quality after thawing, besides the extender, also the cooling curve is a key point for the maintenance of sperm functionality, which seeks to minimize the development of heat shock, the formation of ice crystals. There are no cryopreservation techniques for overall survival after the procedure. The most commonly used spermatic cooling curve generally exhibits freezing rates ranging from 15 to $60{ }^{\circ} \mathrm{C} /$ minute, with the highest rates of sperm survival (WATSON, 2000). In general, the main components of semen extenders are: sugars, proteins or lipoproteins, buffers, cryoprotectants and additives (BWANGA et al., 1991b). The Beltsville Thawing Solution (BTS) is the more widely used extender for this procedure, but alternative extenders are being tested to achieve better post-thawing results. Skimmed milk powder is practical and effective to protect sperm during the storage period; also, the cryoprotectant effect against heat shock (JULIANI; HENRY, 2008). Several studies have been carried out in the search for an ideal spermatozoid cryoprotectant (WILMUT; POLGE, 1977; SCHEID, 1980; BWANGA et al., 1991a). Despite the greater sensitivity of swine spermatozoa to glycerol (FISER, 1991) and with its damaging action to the plasma membrane (BWANGA et al., 1992), no other cryoprotectant have been found that could efficiently replace this one (BORTOLOZZO et al., 2005).

The use of frozen boar semen is still restricted to research improvement and to disseminate genetic material; thus, there is a need for new studies to provide the best sperm cell cryopreservation conditions (SARAIVA et al., 2005). Thus, given the importance of semen conservation for an indefinite period, for the pig industry it is necessary to develop new techniques which allow the use of cryopreserved semen without falling fertility results after thawing (TONIOLLI et al., 1998). This study is aimed at evaluating the extender skimmed milk powder (SMP) and sugar fructose in a new cooling curve for freezing boar semen.

\section{Material and Methods}

The study meets the criteria requested by Ethics Commission on Animal Use of the Stare University of Ceará, and the research project (process 12236467-8) was approved by the Committee on August 31 ${ }^{\text {st }}, 2012$.

For the experiment, animals aged between 12 and 30 months in routine of semen collection system in Laboratory of Swine Breeding and Technology of Semen were used. A total of 49 semen samples from seven boars were collected. Before each collection of total ejaculate, the foreskin was externally cleaned with soap and water. Then, preputial exhaustion was treated by manual pressure on the caudal-cranial direction. Finally, the area was dried with paper towels. The gelatinous fraction, retained by the gauze, was disposed of and the ejaculate, initially, identified and evaluated for volume $(\mathrm{ml})$, concentration $\left(\mathrm{x} 10^{6} \mathrm{sperm} / \mathrm{ml}\right)$, total of sperm $\left(\mathrm{x} 10^{9} \mathrm{spz}\right)$. A total of $15 \mu \mathrm{L}$ of semen was placed between a slide and coverslip and taken under an optical microscope (200x) for assessing the spermatic vigor ( 0 to 5 ) and motility (0 to $100 \%$ ). These tests were used for the evaluation of the ejaculate of each boar individually. Also, to evaluate sperm quality control during the period of the experiment, the ejaculate is tapped to produce the following minimum values: vigour $\geq 3.5$ and $\geq 85 \%$ motility. 
The temperature was controlled throughout the experimental protocol, $\left(35-37^{\circ} \mathrm{C}\right)$, avoiding problems of heat shock upon contact with semen. A total of $2.5 \times 10^{9}$ spz of each ejaculate was separated and then incubated for 15 minutes at $30^{\circ} \mathrm{C}$. Afterward, it was diluted in Beltsville Thawing Solution (BTS) or skimmed milk powder (SMP) at a ratio of 3 vol. of extender: 1 vol. of semen, maintaining the same temperature for 30 minutes. The diluted semen was then moved to centrifuge tubes $(50 \mathrm{ml})$ and kept in a water bath at $25^{\circ} \mathrm{C}$ for 30 minutes. After this period, the tubes were transferred to the dark for 2 hours at $17^{\circ} \mathrm{C}$. Samples were then centrifuged at $800 \mathrm{xg} / 15$ minutes to $5^{\circ} \mathrm{C}$ into the refrigerated centrifuge, discarding the supernatant. Then, the sperm pellet (pellet $-0.5 \mathrm{ml}$ ) was resuspended in 2.25 $\mathrm{ml}$ of extender egg yolk Glucose /Fructose $\left(5^{\circ} \mathrm{C}\right)$ at an initial concentration of $909.1 \times 10^{6}$ cells / $\mathrm{ml}$ (cooling extender) and kept at $5{ }^{\circ} \mathrm{C}$ for 60 minutes (slow cooling). At the end of incubation time at $5^{\circ} \mathrm{C}$, plus $2.25 \mathrm{ml}$ of the freezing extender (egg yolk glucose / fructose $6 \%$ of glycerol) was slowly added to the centrifuge tube, with a final concentration of $500 \times 10^{6}$ cells / $\mathrm{ml}$ for subsequent packaging and freezing. Semen was then packaged in identified straws $(0.5 \mathrm{ml})$ that were sealed with polyvinyl alcohol powder (PVC).

The cooling extender consisted of $5.67 \mathrm{~g}$ of sugar (glucose or fructose), 20\% egg yolk, and added to 100 $\mathrm{ml}$ of distilled water. The extender had the same freezing composition plus $6 \%$ glycerol. The final concentration of glycerol for freezing was $3 \%$.

For freezing procedure, the straws were placed in a freezing ramp of $5 \mathrm{~cm}$ above the liquid nitrogen for 30 minutes at a temperature between -60 to $-70{ }^{\circ} \mathrm{C}$, then immersed in liquid nitrogen $\left(-196^{\circ} \mathrm{C}\right)$. The samples were stored in liquid nitrogen for a time between 48 and 96 hours before thawing.

The contents of each straw were thawed in a water bath at a temperature of $39^{\circ} \mathrm{C}$ for 50 seconds, then added to the resuspension extenders (SMP or BTS) at the same temperature. For in vitro testing, resuspension of unfrozen sample was taken to achieve the concentration of an insemination dose ( $0.5 \mathrm{ml}$ of semen $+2 \mathrm{ml}$ of extender). Once thawed and resuspended, each sample was placed into test tubes in a water bath at $39^{\circ} \mathrm{C}$ for analysis, observing the final concentration of $100 \times 10^{6} \mathrm{spz} / \mathrm{ml}$.

The milk powder was purchased commercially and prepared as follows: $10 \mathrm{~g}$ skimmed milk powder $+0.194 \mathrm{~g}$ glucose $+0.336 \mathrm{~g}$ pencivet, diluted in $100 \mathrm{~mL}$ (1 liter of extender: $100 \mathrm{~g}$ of milk, $1.94 \mathrm{~g}$ of glucose and $3.36 \mathrm{~g}$ of pencivet).
Preparation: milk powder (Molico, Nestlé) were mixed into the total volume of distilled water; glucose was added, then heated for 10 minutes in a water bath at $60^{\circ} \mathrm{C}$ and cooled under cold running water. Finally, the antibiotic was added.

Beltsville Thawing Solution (BTS, Minitub) an extender widely used for dilution of boar semen, purchased in local shops, was used as a control treatment.

The extenders were tested during the cooling curve added by a different sugar and were withdrawn together with the seminal plasma after centrifugation at $5{ }^{\circ} \mathrm{C}$, and after thawing at sample resuspension.

Two different sugars were added to the cooling/freezing extenders in the same way as previously mentioned, and with the same proportion (5.67 g), tested. Then, a $\mathrm{pH}$ and osmolarity control was evaluated, maintaining the characteristics of standard extender: (a) T1 = Glucose (GLU - control); (b) T2 = fructose (FRU). There were four total experimental treatments: BTS G (Beltsville Thawing Solution with Glucose); BTS F (Beltsville Thawing Solution with Fructose); SMP G (skimmed milk powder with glucose) and SMP F (skimmed milk powder with fructose).

A total of six exams of the spermatic vigor (grades between 0-5) (TONIOLLI, 1996) and sperm motility (\% total of motile cells) were made at different points during the cooling curve (Figure 1). By targeting analysis, semen samples of $15 \mu \mathrm{L}$ were taken, placed between a slide and coverslip, heated to $39^{\circ} \mathrm{C}$ for 10 minutes and evaluated by optical microscopy at a magnification of 200x. These analyses were performed in six moments:

- at $30^{\circ} \mathrm{C}$ immediately after dilution 3:1 with BTS and SMP (Exam. 1);

- at $30^{\circ} \mathrm{C}$ after the incubation period (Exam. 2);

- at $25^{\circ} \mathrm{C}$ after the incubation period (Exam. 3);

- at $17^{\circ} \mathrm{C}$ after incubation and before centrifugation (Exam. 4);

- at $5{ }^{\circ} \mathrm{C}$ after centrifugation and cooling extender addition (Exam. 5);

- at $5{ }^{\circ} \mathrm{C}$ after incubation and freezing extender addition (Exam. 6).

A seventh examination (Exam. 7) was taken after thawing / resuspension of semen extenders BTS and SMP, evaluating the following characteristics: spermatic vigor and sperm motility, sperm viability (\% of live cells), acrosome integrity and membrane functionality (osmotic resistance). 


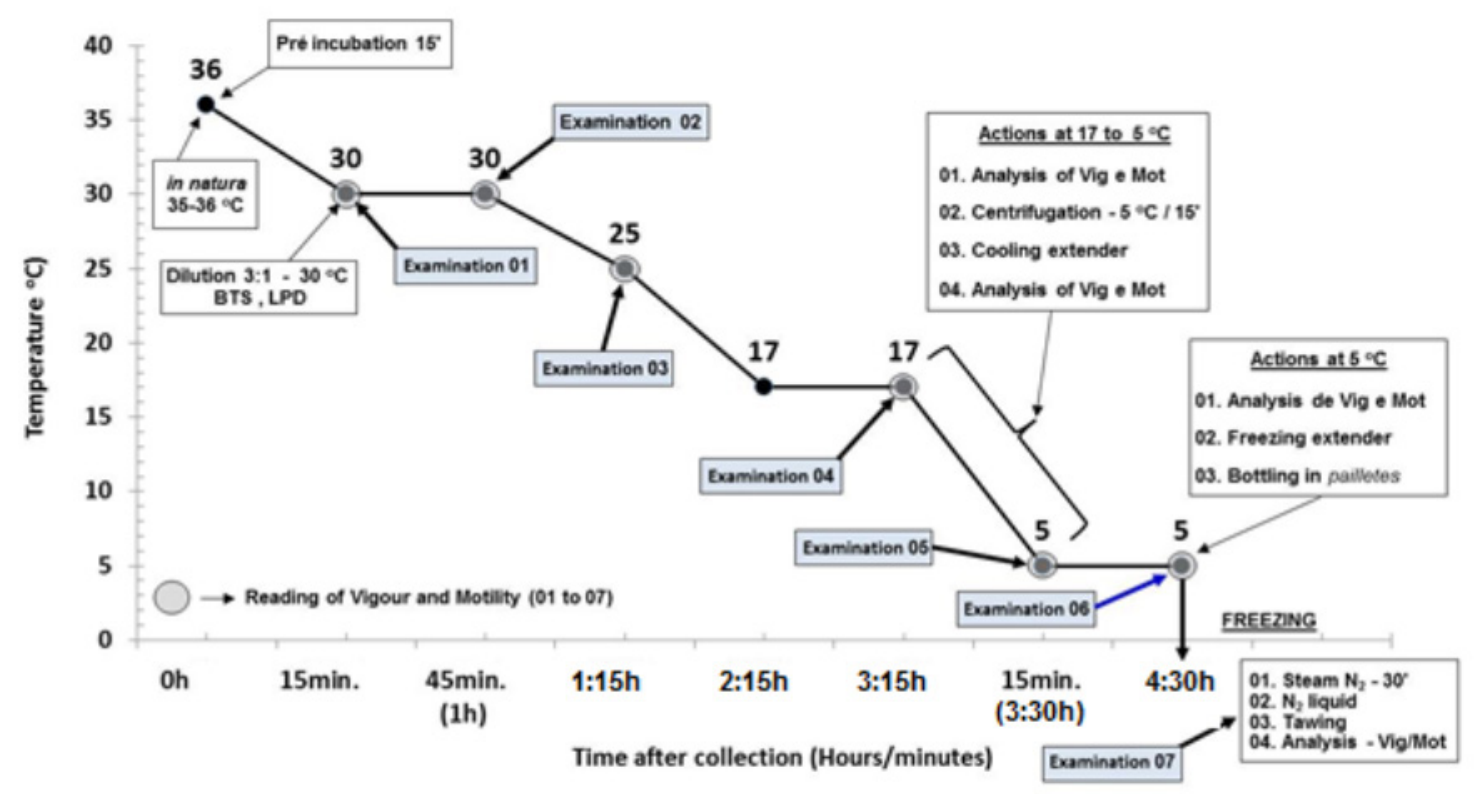

Figure 1 - Analysis points during the new cooling curve

Spermatic vigor represents the strength of sperm movement. It can be classified with a grade $0-5$ (TONIOLLI, 1996), where 0 represents the absence of forward movement with lateral weak displacement tail and inexpressive, and 5 represents a movement the vigorous and speedy sperm, following the predetermined characteristics by table spermatic analysis. Total motility is estimated by the total percentage of cells moving in different fields examined (0-100\%). For both analyses, a seminal drop of the sample $15 \mu \mathrm{L}$ was used between the slide and coverslip and evaluated under an optical microscope at 200x.

Based on the morphological analyses (acrosomal defects) (BORTOLOZZO et al., 2005) and sperm viability (\% of live sperm), semen smears were examined counting 200 cells per stained smear (bromofenol blue) in optical microscopy with immersion lens $(1000 \mathrm{x}=0.4 \mathrm{~g}$; distilled water $=10 \mathrm{ml}$ ), a vital staining that can separate living from dead cells (MEDEIROS et al., 2006). The solution osmolality was measured and adjusted as necessary with distilled water ( 300 and $310 \mathrm{mOsm}-\mathrm{Ol} / \mathrm{kg} \mathrm{H}_{2} \mathrm{O}$ ). To prepare the smear, a drop of semen was mixed with a drop of dye (15 $\mu \mathrm{L}$ each), both at $39^{\circ} \mathrm{C}$; then, it was homogenized. After 30 seconds, a drop $(30 \mu \mathrm{L})$ of this smear preparation mixture was pulled out and dried at room temperature $\left(25^{\circ} \mathrm{C}\right)$ before analysis. According to the acrosome and viability morphology, the sperm were classified into four categories: (i) Live with intact acrosome; (ii) Living with damaged acrosome; (iii) Dead with intact acrosome; (iv) Dead with damaged acrosome (BORTOLOZZO et al., 2005).
The technique of osmotic resistance test consists of adding $1 \mathrm{ml}$ of diluted semen in $15 \mathrm{ml}$ of distilled water and kept for 15 minutes in a water bath at $37^{\circ} \mathrm{C}$ (solution A). After the incubation period, $0.5 \mathrm{ml}$ of $1 \%$ formalin saline (solution $\mathrm{B}$ ) was added in $1 \mathrm{ml}$ of solution $\mathrm{A}$. From this new solution (C), an aliquot part of $15 \mu \mathrm{L}$ was withdrawn and placed on a slide, covered with a coverslip, and then examined under an optical microscope with a 40x magnification, with 200 sperm cells counted (GRAHAM; MOCÉ, 2005). A cell with straight tail is indicative of membrane rupture, the intact membrane has rolled or folded tail.

The experimental design used was randomized blocks. To analyse the normality of the data, the Shapiro Wilk test was conducted, which showed non-normal distribution. Then, the data (extenders $\mathrm{x}$ sugars) were subjected to the Mann Whitney test and Student's t tests. Means and standard deviations of each group were obtained for statistical analysis. The analysis of differences between means was performed using BioStat 5.0 software. An index of statistical significance of $95 \%(p<0.05)$ was also used.

\section{Results and Discussion}

The fraction of fresh semen (raw semen) of 48 ejaculates analysed had a normal appearance, milky white color, average volume of $265.4 \mathrm{ml}$ and mean concentration of $320.6 \times 10^{6} \mathrm{sperm} / \mathrm{mL}$ (by MINITUB spectrophotometer). Such characteristics are within the normal range for swine 
(CORRÊA et al., 2001; SMITAL, 2009). The fresh semen showed a mean of $89.0 \pm 4.2$ (motility) and $4.0 \pm 0.1$ (vigor).

At every temperature point of the cooling curve, a decrease of natural vigor and motility were observed compared with fresh semen. This is due to the decreasing of nutrients present in the extender caused by the sperm and increasing consumption of toxic products of metabolism resulting in the middle cell (CORRÊA et al., 2001).

In the first four points of curve analysis (pre-dilution, $30^{\circ} \mathrm{C}, 25^{\circ} \mathrm{C}$ and $17^{\circ} \mathrm{C}$ ), a total of three hours and fifteen minutes passed after the analysis. Also, a significant difference was observed between the BTS and the SMP extender, in which the SMP mean spermatic vigor was greater than the BTS. According to Memon and Ott (1981), the presence of lipoproteins and milk lecithin promotes sperm cell protection against thermal shock, when it is added to semen before cooling. Also, Meireles et al. (1998) showed that at $4{ }^{\circ} \mathrm{C}$, skimmed milk is an excellent conservative medium for sperm cells, which protects these cells efficiently against cryoinjuries. The averages of the same extenders and different sugars were the same because the fructose and glucose had not yet been added to the extenders. There was no significant difference in average force between extenders and sugars, after adding the cooling and freezing extenders (Table 1).

The analyses of sperm motility were like the analysis of spermatic vigor. However, beyond the first four points of curve analysis, the fifth point (post-cooling extender), a statistical difference was found between the extenders, where again the SMP obtained a higher average compared to the BTS $(61.0 \pm 18.2$ and $74.0 \pm 15.5$, respectively).

Batellier et al. (1998) reported that the SMP has components with beneficial action for gamete. Also, other authors have reported the use of skimmed milk during storage as a substance of practical use and an effective sperm protection even better at preserving sperm motility than other extenders, by liquid form, and the post-thawing (KULAKSIZ et al., 2012). Unlike the other curve points at "post-extender freezing", BTS and SMP extenders presented similar results. Furthermore, there was no significant difference between fructose and glucose in any of the two analysis points (Table 2).

Both motility and spermatic vigor was observed. Also, a better performance in the analysis compared to the BTS was down and less pronounced with the SMP during freezing, extending sperm viability. However, from the exam 5, after nearly four hours of protocol, the equalization of the two extenders was performed, implying that longer periods in the performance of the SMP falls, failing to maintain the same performance.

In the analysis of sperm parameters after thawing, regarding sperm vigor, the statistical difference $(\mathrm{p}<0.05)$ between the two extenders (BTS and SMP), was shown but the average BTS was over the SMP after thawing. These results agree with Kasimanickam et al. (2011), where the SMP was not able to preserve ram semen for a long period due to the deterioration process. No significant difference was observed between sugars (fructose and glucose), but the highest values were found in extenders containing fructose (BTS L: $2 \pm 0.7$; BTS F: $2.1 \pm 0.5$; SMP G: $1.6 \pm 0.9$; SMP F: $1.8 \pm 0.7)$.

Similar to what happened with the spermatic force, the highest percentage of motile cells was observed in BTS, which was significantly higher than the SMP, justifying the fact that the BTS as the most widely used extender in artificial insemination programs. However, it is recommended that an inseminated dose with BTS be processed within 72 hours of storage at $15-18^{\circ} \mathrm{C}$ (ALEXOPOULOS et al., 1996; HUO et al., 2002). Although, the beneficial action of the SMP during cooling curve has already been reported in different studies (MEIRELES et al., 1998), these results are not applicable during the cryopreservation observed in this study. The SMP did not show the best preservation of the organoleptic characteristics of the extender, resulting in the deterioration of its components. This fact may occur during a longer storage period, when this extender should not be used for boar semen (KASIMANICKAM et al., 2011).

There was no statistical difference between the sugars; however, BTS with fructose had the highest average motility $(38.0 \pm 21.1)$ compared to the other treatments. The use of fructose allowed an equalization of values of sperm motility between SMP and BTS. Although the significant difference between these extenders was observed, there was no statistical difference between BTS containing glucose and SMP when fructose was added (35.0 \pm 23.6 and 28.0 \pm 23.1 , respectively) (Table 3 ).

This result can be explained by the fact that sugar maintains the osmotic pressure of the extender, avoiding cell dehydration. Also, it decreases the formation of ice crystals within spermatozoa (PURDY, 2006), interacts with phospholipid membranes, providing membrane stabilization (AISEN et al., 2002; HINCHA et al., 2006), reorganizing it, and from this, increasing the survivability of spermatozoa subjected to cryopreservation (BUCAK et al., 2007). 
Table 1 - Boar sperm vigor at different times and temperatures, during the cooling curve, using different extenders and sugars

\begin{tabular}{lcccc}
\hline \multirow{2}{*}{ Points Cooling Curve } & \multicolumn{4}{c}{ Treatments } \\
\cline { 2 - 5 } & BTS G & BTS F & SMP G & SMP F \\
\hline Exam. 1 & $3.2 \pm 0.6^{\mathrm{a}}$ & $3.2 \pm 0.6^{\mathrm{a}}$ & $3.7 \pm 0.5^{\mathrm{b}}$ & $3.7 \pm 0.5^{\mathrm{b}}$ \\
Exam. 2 & $3.2 \pm 0.6^{\mathrm{a}}$ & $3.2 \pm 0.6^{\mathrm{a}}$ & $3.5 \pm 0.5^{\mathrm{b}}$ & $3.5 \pm 0.5^{\mathrm{b}}$ \\
Exam. 3 & $2.9 \pm 0.6^{\mathrm{a}}$ & $2.9 \pm 0.6^{\mathrm{a}}$ & $3.6 \pm 0.5^{\mathrm{b}}$ & $3.6 \pm 0.5^{\mathrm{b}}$ \\
Exam. 4 & $2.3 \pm 0.7^{\mathrm{a}}$ & $2.3 \pm 0.7^{\mathrm{a}}$ & $2.9 \pm 0.8^{\mathrm{b}}$ & $2.9 \pm 0.8^{\mathrm{b}}$ \\
Exam. 5 & $3.3 \pm 0.7^{\mathrm{a}}$ & $3.3 \pm 0.6^{\mathrm{a}}$ & $3.6 \pm 0.5^{\mathrm{a}}$ & $3.3 \pm 0.5^{\mathrm{a}}$ \\
Exam. 6 & $3.3 \pm 0.5^{\mathrm{a}}$ & $3.3 \pm 0.7^{\mathrm{a}}$ & $3.1 \pm 0.6^{\mathrm{a}}$ & $2.8 \pm 0.8^{\mathrm{a}}$ \\
\hline
\end{tabular}

$\mathrm{A}$ and $\mathrm{b}$ are different letters in the same row significant differences $(\mathrm{p}<0.05)$. Exam. 1 : at $30^{\circ} \mathrm{C}$ after diluting 3:1 with BTS and SMP; Exam. 2: at $30^{\circ} \mathrm{C}$ after the incubation period; Exam. 3: at $25^{\circ} \mathrm{C}$ after the incubation period; Exam. 4: at $17^{\circ} \mathrm{C}$ after incubation and before centrifugation; Exam. 5: at $5^{\circ} \mathrm{C}$ after centrifugation and cooling extender addition; Exam. 6: at $5{ }^{\circ} \mathrm{C}$ after incubation and freezing extender addition. BTS G: Beltsville Thawing Solution + Glucose; BTS F: Beltsville Thawing Solution + Fructose; SMP G: Skimmed Milk Powder + Glucose; SMP F: Skimmed Milk Powder + Fructose

Table 2 - Boar sperm motility at different times and temperatures during the cooling curve, using different extenders and sugars

\begin{tabular}{lcccc}
\hline \multirow{2}{*}{ Points Cooling Curve } & \multicolumn{4}{c}{ Treatments } \\
\cline { 2 - 5 } & BTS G & BTS F & SMP G & SMP F \\
\hline Exam. 1 & $82.6 \pm 10.8^{\mathrm{a}}$ & $82.6 \pm 10.8^{\mathrm{a}}$ & $87.4 \pm 7.0^{\mathrm{b}}$ & $87,4 \pm 7.0^{\mathrm{b}}$ \\
Exam. 2 & $77.5 \pm 13.1^{\mathrm{a}}$ & $77.5 \pm 13.2^{\mathrm{a}}$ & $85.0 \pm 8.2^{\mathrm{b}}$ & $85.0 \pm 8.2^{\mathrm{b}}$ \\
Exam. 3 & $76.0 \pm 11.7^{\mathrm{a}}$ & $76.0 \pm 11.8^{\mathrm{a}}$ & $84.0 \pm 8.8^{\mathrm{b}}$ & $84.0 \pm 8.8^{\mathrm{b}}$ \\
Exam. 4 & $61.0 \pm 18.2^{\mathrm{a}}$ & $61.0 \pm 18.2^{\mathrm{a}}$ & $74.0 \pm 15.5^{\mathrm{b}}$ & $74.0 \pm 15.6^{\mathrm{b}}$ \\
Exam. 5 & $69.0 \pm 11.9^{\mathrm{a}}$ & $72.0 \pm 8.6^{\mathrm{a}}$ & $74.0 \pm 9.6^{\mathrm{b}}$ & $74.0 \pm 9.1^{\mathrm{b}}$ \\
Exam. 6 & $62.0 \pm 19.2^{\mathrm{a}}$ & $67.0 \pm 11.9^{\mathrm{a}}$ & $62.0 \pm 18.1^{\mathrm{a}}$ & $65.0 \pm 15.9^{\mathrm{a}}$ \\
\hline
\end{tabular}

$\mathrm{A}$ and $\mathrm{b}$ are different letters in the same row significant differences $(\mathrm{p}<0.05)$. Exam. 1 : at $30^{\circ} \mathrm{C}$ after diluting 3:1 with BTS and SMP; Exam. 2: at $30^{\circ} \mathrm{C}$ after the incubation period; Exam. 3: at $25^{\circ} \mathrm{C}$ after the incubation period; Exam. 4: at $17^{\circ} \mathrm{C}$ after incubation and before centrifugation; Exam. 5: at $5^{\circ} \mathrm{C}$ after centrifugation and cooling extender addition; Exam. 6: at $5{ }^{\circ} \mathrm{C}$ after incubation and freezing extender addition. BTS G: Beltsville Thawing Solution + Glucose; BTS F: Beltsville Thawing Solution + Fructose; SMP G: Skimmed Milk Powder + Glucose; SMP F: Skimmed Milk Powder + Fructose

It has been suggested that the fertility decline is associated with molecular changes in the plasma membrane of the sperm and production of reactive oxygen types, which lead to instability of the membrane head after thawing (BREININGER et al., 2005).

Regarding the functionality of the cell membrane, the best results were seen in the treatments containing fructose, regardless of the extender, differing glucose (BTS $\mathrm{G}=30.9 ; \mathrm{BTS}=36.9, \mathrm{SMP} \mathrm{G}=30.7 ; \mathrm{SMPF}=36.8$ ). There was no statistical difference $(\mathrm{p}>0.05)$ between the BTS and the SMP (Table 4).

Sugars, as fructose are macromolecules that have their cryoprotective action because they could not penetrate the cells. The obtained results confirmed that sugars can preserve the structural and functional integrity of the cell membrane, giving greater stability to the cell at low temperatures, due to interaction with proteins and glycoproteins membranes.
The rate of sperm vitality (Table 5) were significantly higher in extender containing glucose and SMP with mean $71.8 \pm 12.5$, even when compared with SMP with fructose, proving that this extender is the best adapted to the needs of survival of pig sperm after cryopreservation. Also, Bergeron et al. (2007) reported that in the same way as the egg yolk, milk casein bonds decreases plasma proteins to sperm, reducing the loss of lipids of cell membrane and increasing sperm protection during the cryopreservation process. After the cryopreservation, a natural decrease on the percentage of live cells was observed. This result can be explained by medium changes in its $\mathrm{pH}$ and osmolarity values, because over time, there was a substrate the energy consumption, production of metabolites and changes in the ions balance, also resulting in cell membrane disruption (WATSON, 1995). 
Table 3 - Spermatic vigor and percentage of motility cells of swine sperm, using different extenders and sugars after thawing and resuspending of samples

\begin{tabular}{lcc}
\hline \multirow{2}{*}{ Treatments } & \multicolumn{2}{c}{ After Thawing } \\
\cline { 2 - 3 } & Force & Motility \\
\hline BTS G & $2.0 \pm 0,7^{\mathrm{a}}$ & $35.0 \pm 23.6^{\mathrm{ac}}$ \\
BTS F & $2.1 \pm 0,5^{\mathrm{a}}$ & $38.0 \pm 21.1^{\mathrm{a}}$ \\
SMP G & $1.6 \pm 0,9^{\mathrm{b}}$ & $22.0 \pm 20.1^{\mathrm{b}}$ \\
SMP F & $1.8 \pm 0,7^{\mathrm{b}}$ & $28.0 \pm 23.1^{\mathrm{bc}}$ \\
\hline
\end{tabular}

$\mathrm{A}, \mathrm{b}$ and $\mathrm{c}$ are different letters in the same column significant differences $(\mathrm{p}<$ 0.05). BTS G: Beltsville Thawing Solution + Glucose; BTS F: Beltsville Thawing Solution + Fructose; SMP G: Skimmed Milk Powder + Glucose; SMP F: Skimmed Milk Powder + Fructose

Table 4-Boar semen osmotic resistance, using different extenders and sugars after thawing and resuspending of samples

\begin{tabular}{lc}
\hline Treatments & $\begin{array}{c}\text { Hiposmotic } \\
\text { (300 and } \mathbf{3 1 0 ~} \text { OsmOl/kg H } \mathbf{~ O ) ~}\end{array}$ \\
\hline BTS G & $30.9 \pm 8.2^{\mathrm{a}}$ \\
BTS F & $36.9 \pm 4.8^{\mathrm{b}}$ \\
SMP G & $30.7 \pm 6.7^{\mathrm{a}}$ \\
SMP F & $36.8 \pm 6.6^{\mathrm{b}}$ \\
\hline
\end{tabular}

$\mathrm{A}, \mathrm{b}$ and $\mathrm{c}$ are different letters in the same column significant differences $(\mathrm{p}<0.05)$. BTS G: Beltsville Thawing Solution + Glucose; BTS F: Beltsville Thawing Solution + Fructose; SMP G: Skimmed Milk Powder + Glucose; SMP F: Skimmed Milk Powder + Fructose

Table 5 - Percentage of live swine sperm (viability), using different extenders and sugars after thawing and resuspending of samples

\begin{tabular}{lc}
\hline Treatments & Vitality \\
\hline BTS G & $47.1 \pm 17.1^{\mathrm{a}}$ \\
BTS F & $44.8 \pm 7.2^{\mathrm{b}}$ \\
SMP G & $71.8 \pm 12.5^{\mathrm{c}}$ \\
SMP F & $41.0 \pm 7.2^{\mathrm{d}}$ \\
\hline
\end{tabular}

$\mathrm{A}, \mathrm{b}, \mathrm{c}$ and $\mathrm{d}$ are different letters in the same column significant differences $(\mathrm{p}<0.05)$ BTS G: Beltsville Thawing Solution + Glucose; BTS F: Beltsville Thawing Solution + Fructose; SMP G: Skimmed Milk Powder + Glucose; SMP F: Skimmed Milk Powder + Fructose

Unlike the egg yolk, the protective effect of milk on the sperm cells involves proteins rather than lipids. When comparing the sugars in BTS, a significant difference was observed between glucose and fructose, which showed higher mean glucose compared to fructose (47.1 and 44.8, respectively). In addition, when compared to fructose added to BTS and SMP, there was no statistical difference between the means of living cells between the two extenders. Araújo et al. (2013) demonstrated that the SMP was a great extender for boar semen at lower temperature $\left(10^{\circ} \mathrm{C}\right)$, giving greater protection to sperm cells through higher rates of vitality.

The percentage of intact acrosome was higher on the extender containing glucose, independent of the extender (BTS or SMP), which did not differ when glucose or fructose was added. When comparing the different sugars in all treatments, there was a significant difference when compared in the same extender (Table 6).

Table 6 - Percentage of swine sperm with acrosome integrity, using different extenders and sugars after thawing and resuspending of samples

\begin{tabular}{cc}
\hline Treatments & Acrosome \\
\hline BTS G & $81.8 \pm 7.2^{\mathrm{a}}$ \\
BTS F & $59.5 \pm 7.9^{\mathrm{b}}$ \\
SMP G & $81.4 \pm 14.2^{\mathrm{a}}$ \\
SMP F & $58.5 \pm 7.2^{\mathrm{b}}$ \\
\hline
\end{tabular}

$A$ and $b$ are different letters in the same column significant differences $(p<0.05)$. BTS G: Beltsville Thawing Solution + Glucose; BTS F: Beltsville Thawing Solution + Fructose; SMP G: Skimmed Milk Powder + Glucose; SMP F: Skimmed Milk Powder + Fructose

Weiss et al. (2000) compared the addition of fructose and glucose in extender for freezing canine semen and found a higher percentage of intact acrosomes, $65 \%$, in an extender containing glucose. These data demonstrated a good rate of acrosome integrity with glucose addition as over $80 \%$ of cells were with functional acrosomes after cryopreservation. In sperm cells, more so than motility, the acrosome integrity is important for the events of fertilization, especially for the fusion of sperm cells to the oocyte (ROTA et al., 1997). In addition, other treatments have also shown good results with intact acrosome rates greater than $50 \%$.

\section{Conclusion}

The results obtained demonstrated that in a new cooling freezing curve, BTS is still the best choice for the freezing process of boar semen. Both fructose and glucose presented the same effective spermatic force and motility after thawing, but the best acrosomal integrity was obtained with glucose. Fructose was the best sugar for the maintenance of functional membrane integrity. 


\section{References}

AISEN, E. G.; MEDINA, V. H.; VENTURINO, A. Cryopreservation and post-thawed fertility of ram semen frozen in different trehalose concentrations. Theriogenology, v. 57, n. 7, p. 1801-1808, 2002. doi: 10.1016/ S0093-691X(02)00653-2.

ALEXOPOULOS, C.; BOSCO, C.; SARATSIS, P.; SAOULIDIS, C.; KYRIAKIS, S. The effect of storage time and number of spermatozoa per insemination dose on semen characteristics and fertilizing capacity of boar semen diluted with Beltsville Thaw Solution (BTS) extender. Animal Science, v. 62, n. 3, p. 599-604, 1996. doi: $0.1017 /$ S1357729800015150.

AMANN, R. P.; PICKETT, B. W. Principle of cryopreservation and a review of cryopreservation of stallion spermatozoa. Equine Veterinary Science, v. 7, n. 3, p. 145-174, 1987. doi: 10.1016/S0737-0806(87)80025-4.

ARAÚJO, L. R. S.; DIAS, A. V.; BARROS, T. B.; GUIMARÃES, D. B.; CANTANHÊDE, L. F.; TONIOLLI, $\mathrm{R}$. Adição de betaína ao diluente leite em pó desnatado durante a conservação do sêmen do varrão a $10{ }^{\circ} \mathrm{C}$. Revista Brasileira de Ciências Veterinárias, v. 20, n. 4, p. 234-240, 2013. doi: 10.22409/rbcv.v20i4.458.

BATELLIER, F.; DUCHAMP, G.; VIDAMENT, M.; ARNAUD, G.; PALMER, E.; MAGISTRINI, M. Delayed insemination is successful with a new extender for storing fresh equine semen at $15{ }^{\circ} \mathrm{C}$ under aerobic conditions. Theriogenology, v. 50, n. 2, p. 229-236, 1998. doi: 10.1016/ S0093-691X(98)00130-7.

BERGERON, A.; BRINDLE, Y.; BLONDIN, P.; MANJUNATH, P. Milk caseins decrease the binding of the major bovine seminal plasma proteins to sperm and prevent lipid loss from the sperm membrane during sperm storage. Biology of Reproduction, v. 77, n. 1, p. 120-126, 2007. doi: 10.1095/biolreprod.106.058248.

BORTOLOZZO, F. P.; WENTZ, I.; BENNEMANN, P. E.; BERNARDI, M. L.; WOLLMANN, E. B.; FERREIRA, F. M.; BORCHARDT NETO, G. B. Inseminação artificial na suinocultura tecnificada. Brasil: Porto Alegre, 2005. 185 p. (Suinocultura em ação, n. 2).
BREININGER, E.; BEORLEGUI, N. B.; O'FLAHERTY, C. M.; BECONI, M. T. Alpha-tocopherol improves biochemical and dynamic parameters in cryopreserved boar semen. Theriogenology, v. 63, n. 8, p. 2126-2135, 2005. doi: 10.1016/j.theriogenology.2004.08.016.

BUCAK, M. N.; TEKIN, N. Protective effect of taurine, glutathione and trehalose on the liquid storage of ram semen. Small Ruminant Research, v. 73, n. 1-3, p. 103-108, 2007. doi: 10.1016/j.smallrumres.2006.12.001.

BWANGA, C. O.; ENARSSON, S.; RODRIGUEZMARTINEZ, H. Cryopreservation of boar semen. II: effect of cooling rate and duration of freezing point plateau on boar semen frozen in mini and maxi-straws and plastic bags. Acta Veterinaria Scandinavica, v. 32, n. 4, p. 455461, 1991a.

BWANGA, C. O.; ENARSSON, S.; RODRIGUEZMARTINEZ, H. Deep freezing of boar semen packaged in plastic bags and straws. Reproduction in Domestic Animals, v. 26, n. 3, p. 117-125, 1991b. doi: 10.1111/j.14390531.1991.tb01528.x.

BWANGA, C. O.; MWANZA, A.; RODRIGUEZMARTINEZ, H. Post-thaw motility, acrosome morphology and fertility of deep-frozen boar semen packaged in plastic PVC-bags. In: INTERNATIONAL CONGRESS ON ANIMAL REPRODUCTION, 12., 1992. Hague. Proceedings... The Hague: Icar, 1992. p. 420-422. 1 v.

CORREAA, M. N.; MEINCKE, W.; LUCIA JR., T.; DESCHAMPS, J. C. Inseminação artificial em suínos. Londrina: Printpar, 2001. 181 p.

DERIVAUX, J. Reproducción de los animales domésticos. Traducido por José Gómez-Piquer. Zaragoza: Cribia, 1982. $486 \mathrm{p}$.

GRAHAM, J. K.; MOCÉ, E. Fertility evaluation of frozen/ thawed semen. Theriogenology, v. 64, p. 492-504, 2005.

HINCHA, D. K.; POPOVA, A. V.; CACELA, C. Effects of sugars on the stability and structure of Lipid membranes during drying. Advances in Planar Lipid Bilayers and 
Liposomes, v. 3, p. 189-217, 2006. doi: 10.1016/S15544516(05)03006-1.

HUO, L. J.; MA, X. H.; YANG, Z. M. Assessment of sperm viability, mitochondrial activity, capacitation and acrosome intactness in extended boar semen during longterm storage. Theriogenology, v. 58, n. 7, p. 1349-1360, 2002. doi: 10.1016/S0093-691X(02)00953-6.

JULIANI, G. C.; HENRY, M. Efeito do glicerol, etilenoglicol, acetamida e leite desnatado na criopreservação de espermatozoides equinos. Arquivo Brasileiro de Medicina Veterinária e Zootecnia, v. 60, n. 5, p. 1103-1109, 2008. doi: 10.1590/S0102-09352008000500010.

KASIMANICKAM, R.; KASIMANICKAM, V.; TIBARY, A.; PELZER, K. Effect of semen extenders on sperm parameters of ram semen during liquid storage at $4{ }^{\circ} \mathrm{C}$. Small Ruminant Research, v. 99, n. 2-3, p. 208-213, 2011. doi: 10.1016/j.smallrumres.2011.03.057.

KULAKSIZ, R.; ÇEBİ, Ç.; AKÇAY, E. The effect of different extenders on the motility and morphology of ram sperm frozen or stored at $4{ }^{\circ} \mathrm{C}$. Turkey Journal of Veterinary and Animal Sciences, v. 36, n. 2, p. 177-182, 2012. doi: 10.3906/vet-1103-11.

Medeiros, A. A.; ARAÚJO, A. A.; MOURA, A. A. A.; CAVAlCANTE, J. M. M.; FIGUEIRÊDO, E. L.; RODRIGUES, L. F. S. Utilização do azul de bromofenol conservado a $4{ }^{\circ} \mathrm{C}$ e $29^{\circ} \mathrm{C}$, como método de coloração vital para a avaliação do espermatozoide ovino. Revista Ciência Agrária, v. 46, p. 287-297, 2006.

MEIRELES, L. S.; MALSCHITSKY, E.; NEVES, A. P.; VIEIRA, M. J.; KELLER, A.; HÖTT, A. K.; MORAES, I. M. A.; GARBADE, P.; GREGORY, R. M.; MATTOS, R. C. Leite em pó desnatado não inativado e leite desnatado UHT para a preservação e fertilidade do sêmen equino resfriado. Ciência Rural, v. 28, n. 3, p. 467-470, 1998. doi: 10.1590/S0103-84781998000300019.

MEMON, M. A.; OTT, R. S. Methods of semen preservation and artificial insemination in sheep and goats. World Review of Animal Production, v. 17, n. 1, p. 19-25, 1981.
PURDY, P. H. A review on goat sperm cryopreservation. Small Ruminant Research, v. 63, n. 3, p. 215-225, 2006. doi: 10.1016/j.smallrumres.2005.02.015.

ROTA, A.; STRÖM, B.; LINDE-FORSBERG, C.; RODRIGUEZ-MARTINEZ, H. Effects of equex STM paste on viability of frozen-thawed dog spermatozoa during in vitro incubation at $38{ }^{\circ} \mathrm{C}$. Theriogenology, v. 47 , n. 5 , p. 1093-1101, 1997. doi: 10.1016/S0093-691X(97)00066-6.

SARAIVA, F.; WALLGREN, M.; NAGY, S.; JOHANNISSON, A.; RODRIGUES-MARTINEZ, H. Deep freezing of concentrated boar semen for intrauterine insemination: deffects on sperm viability. Theriogenology, v. 63, n. 5, p. 1320-1333, 2005. doi: 10.1016/j.theriogenology.2004.06.012.

SCHEID, I. R. Tiefgefrierkonservierung von ebersamen in kunststoffrohren erprobung der gefrierschutzsubstanzen glycerin, dimethylsulfoxyd und acetamid. 1980. 98 p. Dissertation (Promotion in Veterinärmedizin) - Tierärztliche Hochschule Hannover, Niederschsen, Deutschland, 1980.

SMITAL, J. Effects influencing boar semen. Animal Reproduction Science, v. 110, n. 3-4, p. 335-346, 2009. doi: 10.1016/j.anireprosci.2008.01.024.

TONIOLLI, R. Pouvoir fecondant des spermatozoides de verrat: amèlioration des conditions de conservation, 1996, 91 p. Thèse (Doctorat en Sciences Biologiques) - Université Francois Rabelais de Tours, Tours, France, 1996.

TONIOLLI, R.; MESQUITA, D. S. M.; CAVALCANTE, S. G. Avaliação in vitro do sêmen de suíno diluído em BTS na água de coco in natura e estabilizada. Revista Brasileira de Reprodução Animal, v. 22, n. 4, p. 198-201, 1998.

WATSON, P. F. Cooling of spermatozoa and fertilizing capacity. Reproduction in Domestic Animals, v. 31, n. 1, p. 135-140, 1995. doi: 10.1111/j.1439-0531.1995.tb00016.x.

WATSON, P. F. The causes of reduced fertility with cryopreserved semen. Animal Reproduction Science, v. 60-61, p. 481-492, 2000. doi: 10.1016/S03784320(00)00099-3. 
WEISS, R. R.; RODASKI, S.; BÜCHELE, J. M.; SANTOS, I. W.; ALMEIDA, L. M. Estudo preliminar de algumas características do sêmen canino congelado. Archives of Veterinary Science, v. 5, n. 1, p. 67-71, 2000. doi: 10.5380/ avs.v5i1.3888.
WILMUT, I.; POLGE, C. The low temperature preservation of boar spermatozoa. 1: the motility and morphology of boar spermatozoa frozen and thawed in the presence of permeating protective agents. Cryobiology, v. 14, n. 4, p. 471-478, 1977. doi: 10.1016/0011-2240(77)90009-8. 